\title{
Shared species of the spontaneous flora of a West African (Burkina Faso) and a Central European country (Germany)
}

\author{
Rüdiger Wittig \\ Institut für Ökologie, Evolution und Diversität, Goethe-Universität Frankfurt, Germany \\ r.wittig@bio.uni-frankfurt.de
}

\begin{abstract}
Summary: In spite of enormous climatic differences between Burkina Faso and Germany, 20 species belong to the spontaneous flora of both countries, i.e. $1 \%$ of the flora of Burkina Faso and $0.5 \%$ of the German flora. All of them are either ruderal and segetal species (16) or water and reed plants (4). All of the 16 ruderals/segetals are therophytes. From a recent point of view, most of the 20 species can be classified as cosmopolitan, because they cover three and more floristic zones, and/or at least three climatic zones, and/or are represented in at least three continents. Although Burkina Faso has a semi-arid climate, none of the species can be called a sclero- or xerophyte. Therefore, in Burkina Faso, all are more or less bound to habitats at least temporarily flooded or to humid soils. In Germany, however, the concerned ruderals, with one exception, are indicators of medium dry or dry habitats.
\end{abstract}

Key words: global change, cosmopolitan, hydrophytes, phytogeography, phytosociology, therophytes, ruderal species, segetal species, indicator values

\section{ESPÈCES COMMUNES dE LA FLORE SPONTANÉE D'UN PAYS OUEST-AfRICAIN (BURKINA FASO) ET D'UN PAYS D'Europe centrale (Allemagne)}

Résumé: En dépit des énormes différences climatiques entre le Burkina Faso et l'Allemagne, 20 espèces appartiennent à la flore spontanée des deux pays, ce qui représente $1 \%$ de la flore du Burkina Faso et $0,5 \%$ de la flore allemande. Toutes ces espèces sont soit rudérales et ségétales (16), soit des plantes aquatiques ou des marais (4). D’un point de vue récent, la plus part des espèces peuvent être classées en tant que cosmopolites. Bien que le Burkina Faso ait un climat semi-aride, aucune de ces espèces ne peut être appelée sclero- ou xérophyte. C'est pourquoi, au Burkina Faso, elles sont toutes plus ou moins liées à des habitats au moins temporairement inondés ou aux sols humides. En Allemagne cependant, en ce qui concerne les espèces rudérales, toutes sauf une sont des indicatrices de milieux semi-arides ou d'habitats secs.

Mots clés: cosmopolite, hydrophytes, valeurs indicatrices, phytogéographie, phytosociologie, espèces rudérales, espèces ségétales, thérophytes

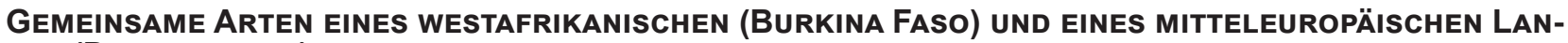 DES (DEUTSCHLAND)}

Zusammenfassung: Trotz großer klimatischer Unterschiede zwischen Burkina Faso und Deutschland gibt es 20 Arten, die in beiden Ländern spontan vorkommen, das sind immerhin $1 \%$ der Flora von Burkina Faso und 0,5\% der Flora Deutschlands. Mehrheitlich handelt es sich dabei um Arten der Ruderal- und/oder Segetalflora (16 Arten), die restlichen sind Wasserbzw. Röhrichtpflanzen. Vom heutigen Standpunkt aus betrachtet, sind die meisten der 20 Arten Kosmopoliten. Obwohl das Klima von Burkina Faso semi-arid ist, gehört keine der Arten zur Gruppe der Sklero- oder Xerophyten. Dementsprechend sind in Burkina Faso alle mehr oder weniger an wenigstens temporär überflutete Standorte oder an feuchte Böden gebunden. 15 der 16 Ruderalen werden in Deutschland dagegen als Indikatoren intermediärer bis trockener Standorte bewertet.

Schlagworte: Hydrophyten, Kosmopoliten, Pflanzengeografie, Pflanzensoziologie, Ruderalarten, Segetalarten, Therophyten, Globaler Wandel, Zeigerwerte

\section{INTRODUCTION}

Regarding the great climatic differences between the Sudanian region of West Africa and Central Europe, it is not surprising that the spontaneous flora of the Sudanian country Burkina Faso and of the Central European Germany do not have many species in common. However, concerning ongoing acceleration of global change, it can be expected that the number of overlapping species will increase. Therefore, in the following, the recent situation is shown, i.e. species jointly present in the spontaneous flora of Burkina Faso and Germany are listed and some ecologic characteristics of these species are shown and discussed.

\section{Methods}

To identify species present in both countries, I compared the "catalogue des plantes vasculaires du Burkina Faso" (THIOMBIANO et al. 2012) with two common floras of Germany, the so-called "Rothmaler" (JäGER 2011) and the "Oberdorfer" (OBERDORFER 2001). For a summary of ecological characteristics, of phytogeography and of biology of the species, the ecological indicator values of the Central European flora (ElLENBERG 1979), the atlas of the ferns and flowering plants of Germany (NeTPHyD\& BFN 2013) and the data collection BIOLFLOR (KLOTZ et al.2002) were used for the German point of view. The Burkinabé part was derived from Ataholo (2001), Wittig 2005 (a,b), OuÉdraogo et al. (2005), Wittig et al. (2011) and Thiombiano et al. (2012). 


\section{Results}

\subsection{General overview}

20 species that have been found occurring spontaneously in Germany are listed in the "catalogue des plantes vasculaires du Burkina Faso" as wild plants, too (Table 1). Two further species mentioned for the spontaneous flora of Germany are cultivated in Burkina Faso. These two species, i.e. Ficus carica and Sorghum bicolor, are not treated in the following.

The species shared between the two countries belong to 11 families, most of them represented by one species only. Amaranthaceae are represented by two, Asteraceae by three and Poaceae by five species (Table 1, column 1). Of the 20 species, 16 belong to the flora of anthropogenic and anthropisised habtitats, i.e. towns, villages, roadsides and other trodden areas, gardens, and arable land (Table 1, column 2). However, in the sense of GRIME (1974), one of them (Eleusine indica) is not a ruderal, but a competitor (Table 1, column 3 ). The four remaining species are strongly bound to waters, because they live submerged (Ceratophyllum demersum), floating (Trapa natans) or in reeds (Phragmites australis, Schoenoplectus litoralis). While three of these four species are perennials, the ruderals are therophytes (Table 1, column 4). In Germany, four of these therophytes are facultative hemicryptophytes.

Regarding pollination vectors (Table 1, column 5) according to Durka (2002), most species concerned (65\%) need no vector but pollinate themselves or are apomictic. However, wind pollination also is important (40). With the exception of Schoenoplectus litoralis, all species are deciduous, showing their leaves during the vegetation period only (ELLENBERG 1979). In Germany, the leaves of the two Sonchus species remain green during winter (Table 1, column 6). Fourteen of the ruderal species have (partly, or can develop) mesomorphic leaves; the leaves of Oxalis corniculata are hygromorphic (Table 1, column 7).

From a recent point of view, $90 \%$ of the species can be classified as cosmopolitan, because they are represented in all continents except Antarctica (Table 1, column 8). But the term "cosmopolitan" does not mean that these species cover all climatic zones (Table 1, column 9). As far as their natural area is known, more species seem to originate from Eurasia (including the entire Mediterrane region) than from Africa South of the Sahara (Table 1, column 10), but only few are indigenous in Germany (Table 2).

Regarding ecological demands and phytosociologic affiliation of the species (Table 2), in Germany, except for Sonchus oleraceus $(\mathrm{T}=5)$, the temperature indicator values assigned by Ellenberg $(1979,1991)$ are higher than 5 (Average 6.8, mean 7), i.e. these species prefer warm habitats. In Burkina Faso, many of the 16 ruderal species are indicators of humid or temporarily flooded soils. Contrarily, in Germany, their indicator value for soil humidity, which is known for ten species, ranges from 6 to 3 (average 4.3, mean 4). I.e., these species, in Germany, are mainly found on intermediate or (slightly) dry soils. The average and the mean indicator for soil reaction of the ruderal/segetal species is 7 (indicator of alkaline soils). This fits well with the fact that, in Burki- na Faso, many of these species mainly grow on argillaceous or loamy soils (THIOMBIANo et al. 2012). According to their phytosociological affiliation in Burkina Faso and their indicator value for nitrogen supply in Germany (Table 2), all ruderal/segetal species can be regarded as indicating soils rich in nutrients.

\subsection{Additional information}

In the following, additional information is given on the 20 species listed in Table 1. All information shown in Table 1, i.e. life form, origin, indicator value in Central Europe, is not repeated.

Amaranthus hybridus L: In Germany, according to NETPhyTD \& BFN (2013), most information on this species is doubtful, because it is often not clear, whether its mentioning in literature refers to $A$. hybridus L. s. str. or to $A$. hybridus agg. However, it is clear, that $A$. $h$. s. str. has been found occasionally in Germany - its first finding could be dated to 1950 (JÄGER 2011) - but that it is not established Germany up to now. In Burkina Faso, it is used as ingredient of sauces (WitTIG \& MARTIN 1995) and has numerous applications in traditional medicine (NACOULMA-OUÉDRAOGO 1996). Therefore, it is tolerated in the vicinity of villages. However, considering the releves of ruderal and segetal communities available up to now (BöHM 2001, KÉRÉ 1998, and Wittig et al. 2011), compared to some other Amaranthus species, it seems to be rare. The African Plant Database (CJB 2012), in the following abbreviated as APD does not even indicate it for Burkina Faso.

Bidens pilosa L. too, is not indicated for Burkina Faso by APD. Also its phytosociological documentation is very sparce. In the region of Tenkodogo, KÉRÉ (1998) found it in three of fife releves of a comparatively undisturbed savanna type. HoFf \& BRISSE (1983) estimate that it is characteristic of a pantropical class of young postcultural vegetation, the class Soncho-Bidentetea pilosae Hoff et al. 1983. In Germany, it is very rare and not established.

Celosia argentea L.: In both countries, this species, originating from Asia, is sometimes cultivated as ornamental plant. While it is naturalized in Burkina, the rare findings in Germany probably are garden escapees, i.e this species is not established.

Ceratophyllum demersum L. is a submerged water plant, but is not strictly bound to permanent waters, because its turions can survive in muddy soil. APD does not indicate it for Burkina Faso. In Germany, it belongs to the most frequent water plants.

Chamaesyce prostrata (Aiton) Small, conservatively named Euphorbia prostrata Aiton by THIOMBIANo et al. (2012), is the only chamaephyte among the 16 ruderals under concern. It is neither indicated by APD for Burkina Faso nor by the Atlas for Germany.

Echinochloa crus-galli (F.) P.Beauv. is only very briefly described by Thiombiano et al. (2012) and not indicated by APD. We can therefore conclude that this species in Burkina Faso is very rare. In Germany, it is a frequent, well-established archaeophyte. 


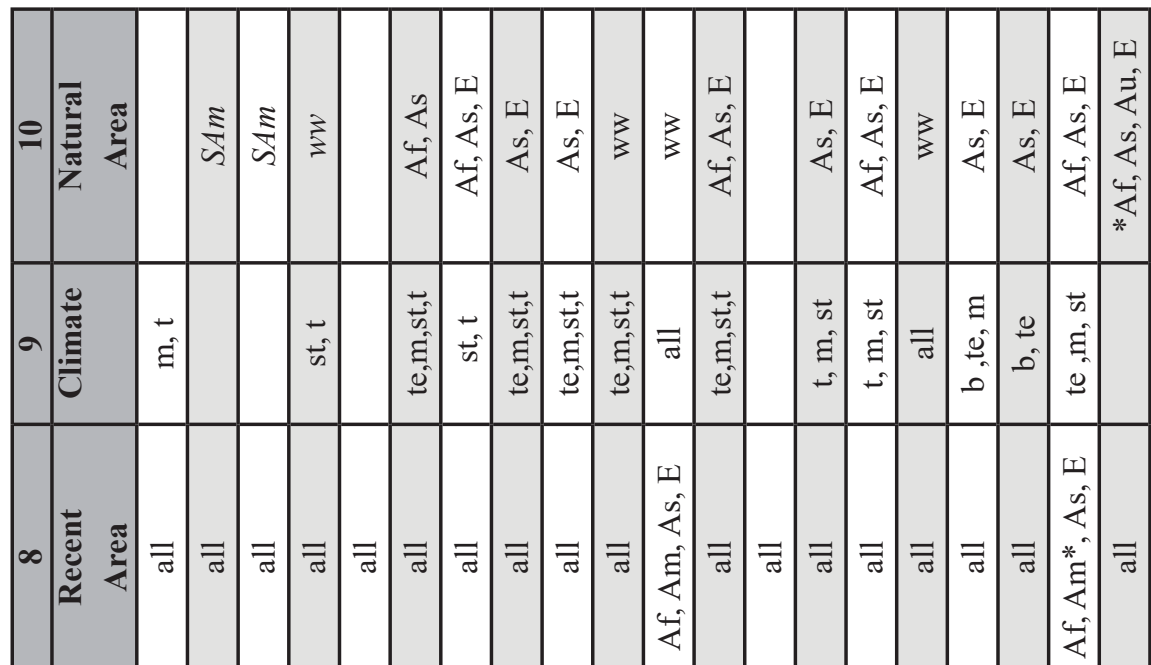

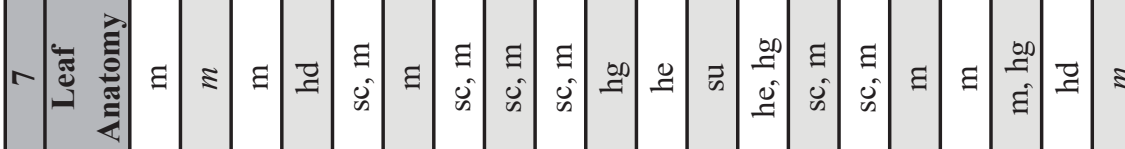

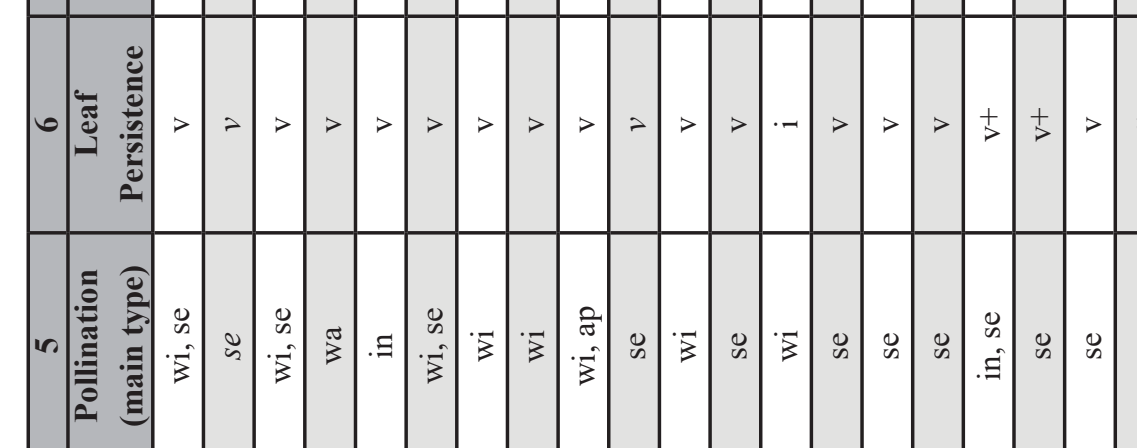

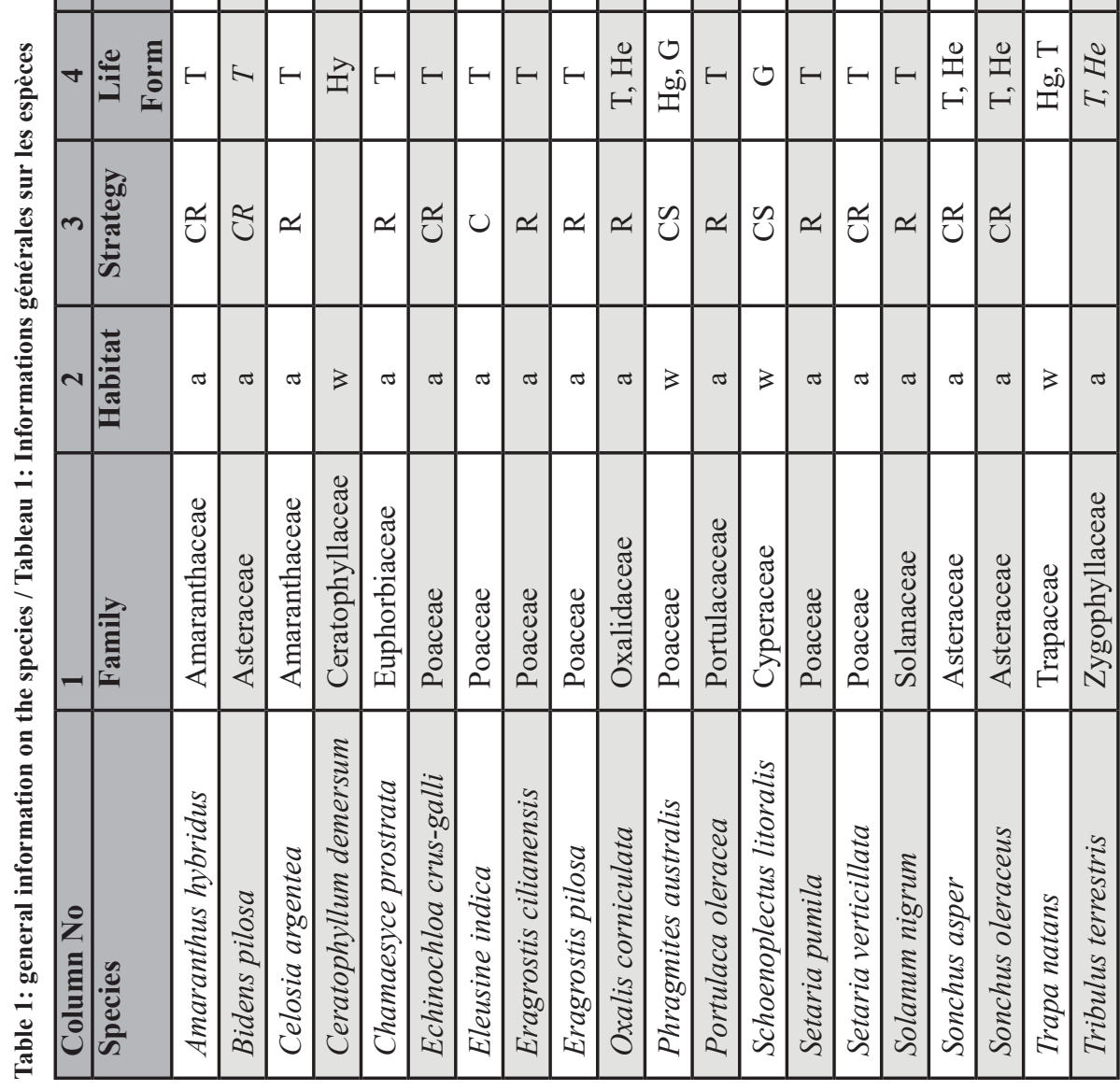

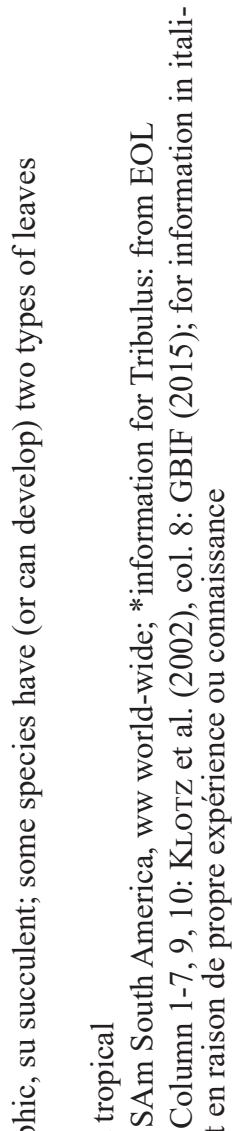

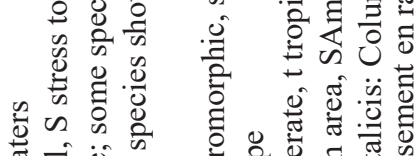
踏苍它

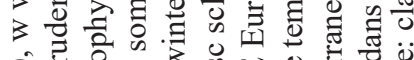

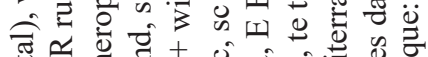

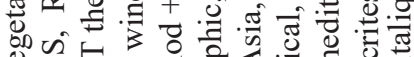

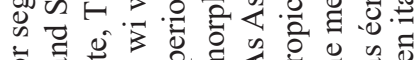

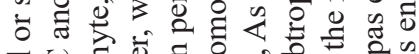

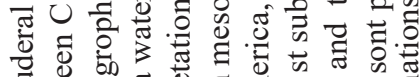

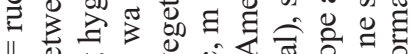

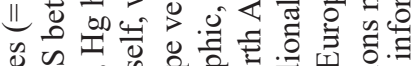
象记出

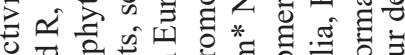

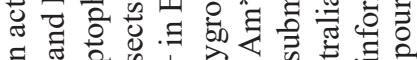

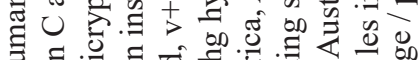
छี

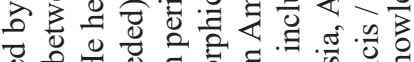

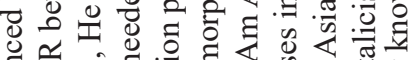

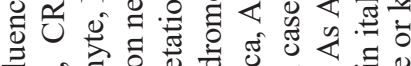

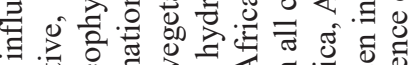

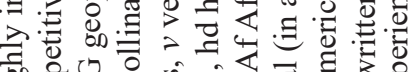
क्ञ

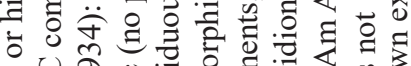
৩

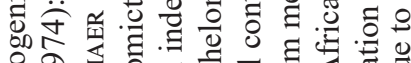
으

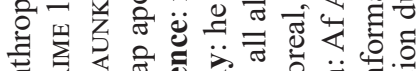

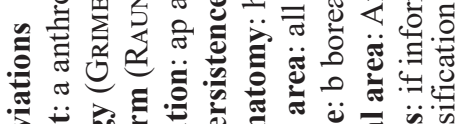

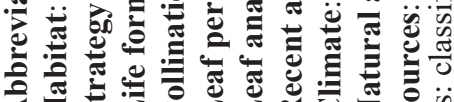



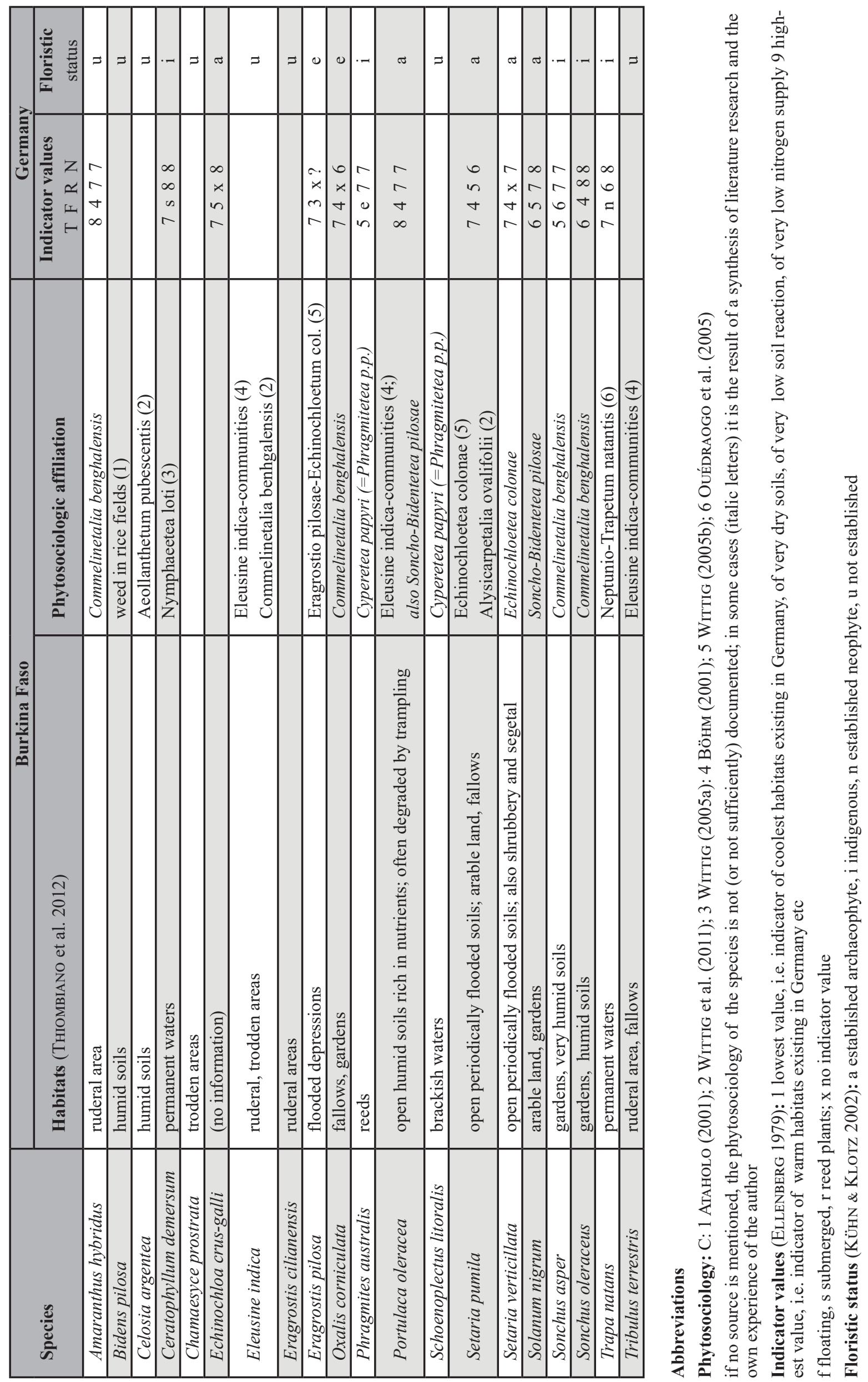

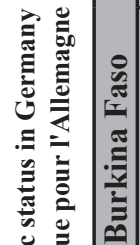

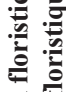

כ)

党

离

ก

สิ

:

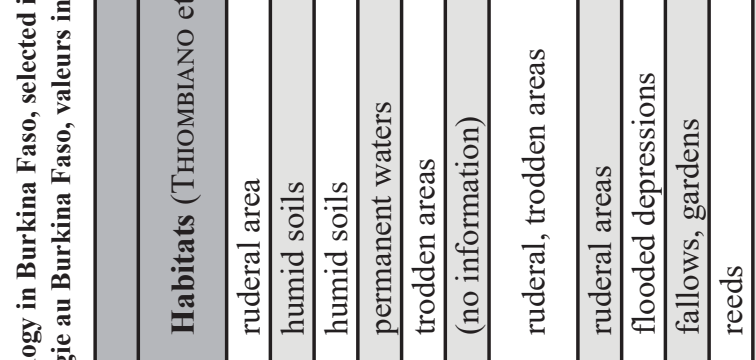

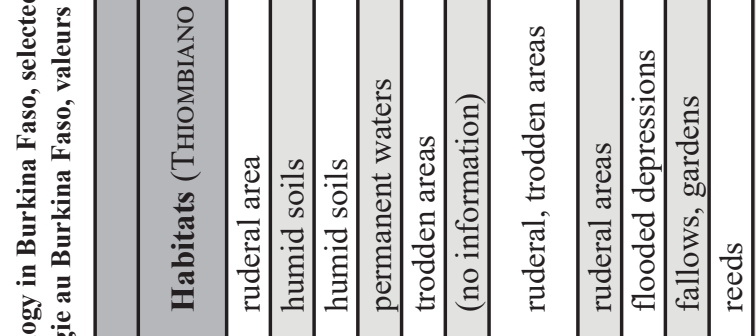
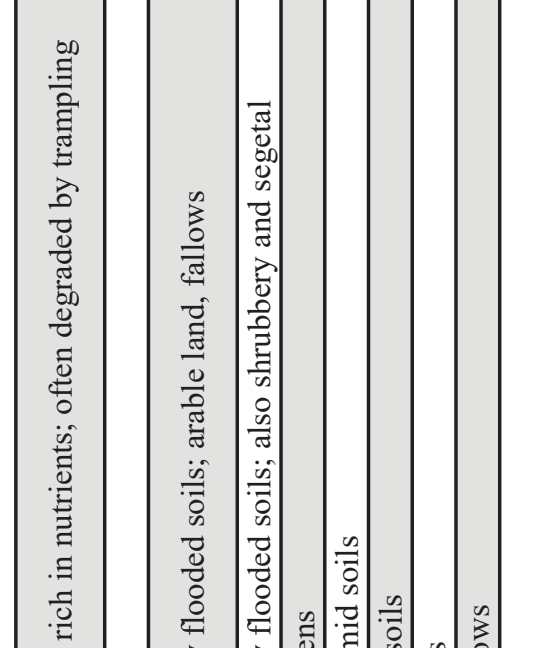
Eleusine indica (L.) Gaertn. has been ranked as character species of the alliance Eleusinion indicae Schmitz 1971 which was described for paleotropical communities of trodden areas (Schmitz 1971). In Burkina Faso, E.i. is very frequent, in Germany very rare and not established.

Eragrostis cilianensis (All.) Vignolo ex Janch is scarcely represented in Bukina Faso's phytosociologic literature, however very well by herbarium specimen in Ouagadougou and Frankfurt. In Germany it is very rare, but a comparison of older with more recent editions of the most common Floras of Germany reveals that it is recently expanding on trodden areas.

Eragrostis pilosa (L.) P.Beauv. was identified by WitTIG (2005) as diagnostic species of the Eragrostio pilosae-Echinochloetum colonae, one of the typical plant communities of temporarily flooded depressions (bas fonds) in the Sahelian zone of Burkina Faso. In Germany, it is obviously expanding and much more frequent than E. cilianensis.

Oxalis corniculata L.: For this species, Thiombiano et al. (2012) give only one reference and mention no herbarium specimen. Obviously this species, which becomes more and more common in Germany, is rare in Burkina Faso. Because no natural habitat is known for O.c., we can assume that it has developed on anthropogenic or anthropisised sites, i.e. it is an anecophyte (SCHOLZ 1995)

Phragmites australis (Cav.) Steud. is very common in Germany. APD does not indicate it for Burkina Faso.

Portulaca oleracea L.: In both countries, $P$. o. is occasionally cultivated, because some people eat it as salad. Therefore, we cannot exclude, that some plants found growing spontaneously might be garden escapees. Nevertheless it can be regarded as established in Burkina Faso and Germany. Like Oxalis corniculata, it is an anecophyte.

Schoenoplectus litoralis (Schrad.) Palla is very rare in both countries. In Burkina Faso it might be indigenous, in Germany it is not established.

Setaria pumila (Poir.) Roem. et Schult., in the phytosociological literature of Burkina Faso documented by numerous releves (mostly named Setaria pallide-fusca), is a diagnostic species of the Setario pallidae-fuscae Echinochloetum colonae Wittig 2005, one of the typical plant communities of temporarily flooded depressions (bas fonds) in the Sahelian zone of Burkina Faso. It is the only plant of the 20 species concerned, which is more or less common in both countries.

Setaria verticillata (L.) P.Beauv. is only scarcely represented in the phytosociological literature of Burkina Faso. In Niger, it is often associated to Echinochloa colona (PoILECOT 1999), i.e. it might be characteristic of the alliance Echinochloion colonae Wittig 2005.

Solanum nigrum L., Sonchus asper (L.) Hill and Sonchus oleraceus L. are frequent in Germany, but not mentioned for Burkina Faso by APD. In the rich phytosociologic literature existing for Burkina Faso, they are only scarcely mentioned. Therefore we can estimate that they are rare in Burkina Faso. Perhaps they are affiliated to the class SonchoBidentetea pilosae Hoff et al. 1983. Solanum nigrum is an anecophyte.
Trapa natans L.: Like the three water and reed species mentiond above, T. $n$. is not indicated for Burkina Faso by APD, but herbarium specimen exist from different lakes and mares (see Thiombiano et al. 2012) and its phytosociology was documented by OUÉDRAOGO et al. (2005). In Germany, it is very rare.

Tribulus terrestris L. is common in Burkina Faso, from where it is particularly documented for (mainly Sahelian and North-Sudanian) ruderal communities degraded by trampling (BöHм 2001). For Germany, it is the rarest one of the 20 species treated in this publication (mentioned by JAEGER 2011, but neither by OBERDORFER 2001 nor by the Atlas).

\section{Discussion}

With regard to the climatic differences - Germany has a temperate climate with rain comparatively equally distributed all over the year, while Burkina Fasos climate is semiarid - it could not be expected that the spontaneous flora of these countries contains 20 shared species. Not surprisingly, most of the species are therophytes occurring only on anthropogenic or disturbed habitats. In Germany, seven of them are classified as (strongly) urbanophilic (Amaranthus hybridus, Celosia argentea, Chamaesyce prostrata, Eleusine indica, Eragrostis cilianensis, Eragrostis pilosa, Portulaca oleracea) meaning that they occur mainly or only in urban areas (WiTtig et al. 1985, KLOTZ \& KüHN 2002).Obviously they are not able to compete with indigenous species (nor in Germany, nor in Burkina) so that they can only survive on places where competition is reduced notably. And of the aquatic and semi-aquatic plants, which represent the rest of the species treated, it is well known that they less depend on climate than terrestrial plants, because regional climatic differences are locally mitigated by large waters. In Burkina Faso, interestingly even the 16 ruderals are more or less bound to humid or temporarily flooded soils. That these species in Germany are regarded as indicators of only intermediately humid or even dry soils, is a confirmation of the rule of habitat constancy established by WALTER \& WALTER (1953).

Although all species treated here are cosmopolitan, most of the 16 ruderals are not very frequent, neither in Germany nor in Burkina Faso. Exceptions are Echinochloa crus-galli, Oxalis corniculata, Solanum nigrum and the two Sonchus species for Germany, as well as Eleusine indica, Setaria pumila and Tribulus terrestris for Burkina Faso. In the maps shown by The African Pant Database (CJB 2012), only eight of these 16 species are indicated for Burkina Faso. In Germany, Echinochloa crus-galli, Oxalis corniculata, Setaria pumila, S. verticillata and Solanum nigrum have shown increasing frequency and expanded their area during the past three or four decades; the two Eragrostis species are expanding recently. Therefore, it can be expected that some of those species of Table 1 that are presently rare in Germany, will expand in the future, due to increasing temperatures and traffic. For Burkina Faso, the direction of climate change and its interaction with the rapid population increase is discussed contrarily (e.g. Scheiter \& Higgins 2008, Heubes et al. 2011). Therefore, it is not possible to predict, whether 
more species that up to now only occur in temperate regions of the world, will immigrate to Burkina Faso or escape from ornamental gardens, where some of them are cultivated.

Regarding the four water and reed species, Ceratophyllum demersum and Phragmites australis are very common in Germany, while Schoenoplectus litoralis and Trapa natans are extremely rare. Surprisingly, none of them is shown for Burkina Faso in the maps of the African Plant Database (CJB 2012). Therefore, we can conclude that they are generally rare. However, for Ceratophyllum demersum and Trapa natans, it is confirmed that they are locally frequent (Ouedraogo et al. 2005). Obviously, floristic research in Burkina Faso is still worthwhile.

\section{ACKNOWLEDGEMENTS}

The author is indebted to Dick Byer and Sebastian Wittig for improvement of the English, and to Karen Hahn and Julia Krohmer, who translated title, summary and key words into French.

\section{RefERENCES}

Aтаноlo M (2001): Pflanzensoziologische Untersuchungen der Segetalvegetaion der DSudanzone Westafrikas. Diss FB Biol Goethe Univ Frankfurt a.M., 2 Bde

Böнм M (2001): Dorfvegetation im Sahel und Subsahel von Burkina Faso. Ber SFB 268, Bd 17: 193-227

CJB (=Conservatoire et Jardin Botanique Ville de Geneve) (2012): African Plant Database. http://www.ville-ge.ch/musinfo/bd/cjb/africa/index.

Durka W (2002): Blüten- und Reproduktionsbiologie. Schriftenreihe Vegetationskunde 38: 133-175

Ellenberg H (1979): Zeigerwerte der Gefäßpflanzen Mitteleuropas, 2. Aufl. Scripta Geobot 9: 1-91

EllenBERG H (1991): Zeigerwerte der Gefäßpflanzen. Scripta Geobot 18: 5-166

EoL (=Encyclopedia of Life) http://eol.org/search visited 2015-12-15

GBIF (=Global Biodiversity Information Facility) http:// www.gbif.org visited 2015-12-16

GRIME JP (1974): Vegetation classification by reference to strategies. Nature 250: 26-31

Heubes J, KüHn I, KöNig K, Wittig R, Zizka G \& Hahn $\mathrm{K}$ (2011) Modelling biome shifts and tree cover change for 2050 in West Africa. J Biogeogr 38: 2248-2258

Hoff M \& Brisse H (1983): Proposition d'un schéma synthétique des végétations secondäires intertropicales. Colloq Phytosoc 12: 249-267

Hoff M, Brisse H \& Grandjouan G (1983): La végétation ruderale et anthropique de la Nouvelle Calédonie. Colloq Phytosoc 12: 197-248

JÄGER EJ (Hrsg) (2011): Rothmaler Exkursionsflora von Deutschland.Gefäßpflanzen: Grundband. Spektrum, Heidelberg, 930p

KÉRÉ U (1998): Vegetation und Wildpflanzennutzung in der Region Tenkodogo (Burkina Faso) / Végétation et utilisation des plantes spontanées dan la région de Tenkodogo (Burkina Faso). Etudes flor vég Burkina Faso 4: 3-55

KLOTZ S \& KÜHN I (2002): Indikatoren des anthropogenen Einflusses auf die Vegetation. Schriftenreihe Vegetationskunde 38: 241-246
KLOTZ S, KüHN I \& DuRKA W (2002): BIOLFLOR - Eine Datenbank mit biologisch-ökologischen Merkmalen zur Flora von Deutschland. Schriftenreihe Vegetationskunde 38, BfN, Bonn, 334p + DVD

KüHN I \& KLOTZS S (2002): Floristischer Status und gebietsfremde Arten. Schriftenreihe Vegetationskunde 38:4756

Nacoulma-Ouédraogo O (1996): Plantes médicinales et pratiques médicinales au Burkina Faso: Cas du plateau central. Tome I. These de'Etat ès Sciences Naturelles, Université de Ouagadougou

NetPhytD \& BFN (2013): Verbreitungsatlas der Farn- und Blütenpflanzen Deutschlands. BfN, Bonn, 912p

OBERDorfer E (2001): Pflanzensoziologische Exkursionsflora für Deutschland und angrenzende Gebiete. Ulmer, Stuttgart, 1051p

OuÉDraogo RL, Guinko S \& WitTig R (2005): La vegetation aquatique et semi-aquatique du Mare aux Hippopotames et des Mares dOursi et Yombolo (Burkina Faso). Etudes flor vég Burkina Faso 9: 19-33

Poilecot P (1999): Les Poaceae du Niger. Boissieria 56, Conservatoire et Jardin botaniques de Genève, Geneva. $766 \mathrm{p}$

RAUNKIAER C (1934): The life forms of plants and statistical plant geography. Clarendon, Oxford. Reprint 1977, Arno, New York, 632p

SCHeiter S, Higgins SI (2008): Impacts of climate change on the vegetation of Africa: an adaptive dynamic vegetation modelling approach. Global Change Biol 15: 2224-2246

Schmitz A (1971): Le vegetation de la Plaine de Lumbumbashi (Kaut-Katanga).I.N.E.A.C. Bruxelles, ser sc 113, 338p

Scholz H (1995): Das Archäophytenproblem in neuer Sicht. Schriftenreihe Vegetationskunde 27: 431-439

Thiombiano A, Schmidt M, Dressler, OuÉdraogo A, HaHN K \& ZiZKA G (2012): Catalogues des plantes vasculaires du Burkina Faso. Biossiera 65, Conservatoire et Jardin botaniques de Genève, Geneva, 391p

Walter H \& Walter E (1953): Einige allgemeine Ergebnisse unserer Forschungsreise nach Südwestafrika 1952: Das Gesetz der relativen Standortkonstanz; das Wesen der Pflanzengemeinschaften. Ber Deutsche Bot Ges 66: 227235

WitTIG R (2005a): The syntaxonomy of the aquatic vegetation of Burkina Faso. Etudes flor vég Burkina Faso 9: 3-10

Wittig R (2005b): Echinochloetea colonae classis nova. Etudes flor vég Burkina Faso 9: 11-18

Wittig R \& Martin R (1998): Krautige Wildpflanzen in der Provinz Tapoa und ihre Nutzung für die menschliche Ernährung. Ber SFB 268 Bd5: 203-212

Wittig R, Diesing D \& GöDde M (1985): Urbanophob urbanoneutral - urbanophil Das Verhalten der Arten gegenüber dem Lebensraum Stadt. Flora 177: 265-282

Wittig R, Becker U \& Ataholo M (2011): Weed communities of arable fields in the Sudanian and the Sahelian zone of West Africa 
Wittig $R$. 